\title{
Usage of Mobile Phones Among Flood Victims in Malaysia
}

\author{
Aini Maznina A. Manaf \\ International Islamic University Malaysia \\ maznina@iium.edu.my \\ Tengku Siti Aisha Tengku Azzman \\ International Islamic University Malaysia (IIUM) \\ taisha@iium.edu.my \\ Saodah Wok \\ International Islamic University Malaysia \\ wsaodah@iium.edu.my
}

\begin{abstract}
One of the worst flood disasters in Malaysian history that occurred in December 2014 had caused much damage including to lives, houses, and material possessions. Large parts of the country, mainly in the East Coast states of Kelantan, Terengganu, and Pahang were severely affected. This study was conducted to explore the use of the mobile phone during the 2014 Malaysian flood. A cross-sectional survey involving a total of 507 respondents who live in flood-affected areas was conducted to examine the use of the mobile phone and the satisfaction obtained from its usage. Being active users of the mobile phone, flood victims mainly used it to obtain information about the flood situation in their community and to communicate with close family members. Furthermore, mobile phones were used to gratify social, entertainment, and mobility needs. Findings of the study will have implications on uses and gratifications, mobile phone use, and natural disasters.
\end{abstract}

Keywords: communication, flood, mobile phone use, natural disaster, uses and gratifications

\section{INTRODUCTION}

In recent years, it has been painful to see the enormous impact that natural disasters including earthquake, hurricane, tsunami, flood, fire and tornado brought to the affected people such as death, injury, and devastation of lives and property (Anthony \& Sellnow, 2011; Tanner et al., 2009). Similarly, Malaysians had a traumatic experience during the 2014 flood incidence that severely affected a large part of the country (Tengku Siti Aisha et al., 2015). Heavy rains and winds that occurred in most parts of the country during the monsoon season resulted in major floods from December 2014 until January 2015. This is among the worst flood disasters in the history of Malaysia, and it was widely captured in the local and 
international media. Several news agencies, among them the BBC and $\mathrm{ABC}$, reported that more than 200,000 people were affected with 100,000 of them evacuated to the evacuation centres provided by the government (Reuters, 2014). During a disaster, people tend to use the media more frequently especially to seek information and to know about the well-being of family members and friends.

Despite the vast number of past studies on disaster communication (Bunce et al., 2012; Hoppszallern, 2014; Tanner et al., 2009; Tengku Siti Aisha, 2015; Umihara \& Nishikitani, 2013), very few studies have focused on mobile phone usage especially among victims or those who live in the affected areas. Notably, most of the previous studies of natural disaster examined mainly the usage of the social media (Bunce et al., 2012; Cho \& Park, 2013; Liu et al., 2015; Simon et al. 2014; Tengku Siti Aisha et al., 2015) although other media such as the mobile phone is also worth studying. Meanwhile, in the disaster communication literature, past studies had examined various contexts of natural disasters such as tsunami (Perry, 2007), hurricane (Anthony \& Sellnow, 2011; Kryvasheyeu, 2015), and wildfires (Suton et al., 2008). However, another natural disaster, i.e., flood, which potentially brings enormous impact to a country including Malaysia is also worth exploring.

Therefore, to gain a better understanding of disaster communication, this study is designed to examine mobile phone usage among flood victims in Malaysia. Specifically, the objectives of this study are as follow:

- To examine patterns of mobile phone usage during the 2014 flood in Malaysia.

- To identify reasons for using the mobile phone during the 2014 flood in Malaysia.

- To explore the relationships among age, perceived importance of the mobile phone, gratifications obtained when using the mobile phone, and mobile phone usage during the 2014 flood in Malaysia.

\section{LITERATURE REVIEW \\ The Role of the Mobile Phone in Disaster Communication}

In the current communication technology era, the mobile phone is getting increasingly popular and highly used by the people in Malaysia. In a study conducted by the Malaysian Communications and Multimedia Commission (MCMC), it was found that Malaysians formed the bulk of hand phone users in the country, accounting for $87.9 \%$ of the subscriber base (MCMC, 2014). Non-Malaysians made up the rest, comprising $12.1 \%$. In terms of age, the survey results showed that hand phone users were dominated by young adults in the 20-24 years old age group representing $18.8 \%$ of the users, followed by the $25-29$ years old age group, which accounted for $16.3 \%$. Regarding gender, the survey results indicated that male users outnumbered female users with $56.9 \%$ against $43.1 \%$.

In recent years, the mobile phone has become very popular among the people due to its portability feature; it is easy to carry everywhere and is multifunctional. In the survey conducted by the MCMC in 2014, about two-thirds (63.3\%) of mobile phone users accessed the Internet through their smartphones. Apart from social function, the mobile phone is also popular due to its mobile and multiple functions, which explains the extensive use of mobile phones among people around the world including Malaysia. The various communication modes provided by mobile phones include text, voice calls, video calls, and instant messaging via pre-paid and pay-as-you-go service, which collectively make it easy for people to 
communicate with each other in a variety of ways at any time. In a study conducted by J-F et al. (2014), mobiles phones seem to fulfil a fundamental need to communicate and to be connected with peers as most of the participants reported that they used their mobile phones to have conversations either through voice calls or more preferably through text messages.

In the event of a disaster or crisis, people will look for information on how the event will affect them and also, what they should do (Tanner et al., 2009). They tend to look for this information from the media, ranging from television, radio, newspaper to the Internet, which is the most popular source of information nowadays and can be accessed via the mobile phone. People who are involved in a crisis or disaster tend to use the mobile phone more than other media to obtain information and communicate with others as it is portable and multifunctional. In a study conducted by Kavanaugh et al. (2010), the mobile phone was highly used during the shooting incident that occurred at the Virginia Technology (VT) campus. Students and faculty staff of the VT heavily used voice and text messaging via cell phones as well as emails via computers as part of their communication media during the crisis.

\section{Mobile Phone Uses and Gratifications}

Unlike the other media influence theories, e.g., magic-bullet and hypodermic needle theories that treat the audience as passive and can be easily manipulated, uses and gratifications theory $(\mathrm{U} \& \mathrm{G})$, on the other hand, rests on the ground that media audiences are active (Blumler \& Katz, 1974; Tanta et al., 2014). Uses and gratifications "have always provided a cutting-edge theoretical approach in the initial stages of each new mass communication medium: newspapers, radio and television and now the Internet" (Ruggiero, 2000, p.1) and mobile applications and devices (Al-Barashdi, 2015; Ho \& Syu, 2010; Hoştut, 2010; Stafford \& Gillenson, 2004). Moreover, this theory assumes that the power is placed in the hands of the media user and is useful in understanding media usage, exposure, and effects.

The uses and gratifications theory ( $U \& G$ ) has been widely used by scholars to understand why and how people actively seek out certain media to satisfy certain needs (Al-Barashdi et al., 2015; Ho \& Syu, 2010; Tanta et al., 2014). This theory is commonly used to explain the motivation to use technology and why people use media to satisfy their social and psychological needs. This process of media use works as follows: "(1) the social and psychological origins of (2) needs, which generate (3) expectations of (4) the mass media or other sources, which lead to (5) differential patterns of media exposure (or engagement in other activities), resulting in (6) need gratifications and (7) other consequences, perhaps mostly unintended ones" (Katz, Blumler, \& Gurevitch, 1973, p. 510). Therefore, U\&G conceptualises media use as a means of satisfying individual needs. Notably, researchers classify audiences' needs and gratifications into several categories, among others, for diversion (to escape from problems, emotional release), personal relationships (social utility of information in conversation, substitution of the media for companionship), personal identity (value reinforcement, self-understanding), and information (Chen et al., 2014; Robin et. al., 2006; Tanta et. al., 2014). Remarkably, audiences selectively use the media to fulfil their individual needs, motives, and interests.

Previous uses and gratifications research on mobile phones indicates that the uses include dimensions of instrumentality, sociability, reassurance, immediate accessibility, status and fashion, entertainment, communication facilitation, relationships, information sharing, self-identity and conforming, self-development and safety, freedom and privacy, self-expression and gossip, and mobility (Al-Barashdi, Bouazza, Jabur, \& Zubaidi, 2015; 
Dimmick et al., 1994; Höflich \& Rössler, 2001; Hoştut, 2010; Leung \& Wei, 2000; Özcan \& Koçak, 2003; Mazzoni et al., 2007; Wei, 2006). A summary of previous U\&G research on mobile phones is presented in Table 1 below.

\section{Table 1: A Typology of Past Uses and Gratifications Research On Mobile Phones}

\begin{tabular}{|c|c|c|}
\hline Author (s) & Year & Use of Mobile Phone and Gratification Typology \\
\hline $\begin{array}{l}\text { Dimmick, Sikand, and } \\
\text { Patterson }\end{array}$ & 1994 & Three gratifications: sociability, instrumentality, reassurance \\
\hline Leung and Wei & 2000 & $\begin{array}{l}\text { Seven gratifications: fashion/status, affection/sociability, } \\
\text { relaxation, mobility, immediate access, instrumentality, } \\
\text { reassurance }\end{array}$ \\
\hline Özcan and Koçak & 2003 & $\begin{array}{l}\text { Three gratifications: status/relaxation, instrumentality/ } \\
\text { business, security/sociability }\end{array}$ \\
\hline Wei & 2006 & $\begin{array}{l}\text { Five gratifications: joy/pleasure, sociability, reassurance, } \\
\text { instrumentality, communication facilitation }\end{array}$ \\
\hline $\begin{array}{l}\text { Mazzoni, Castaldi, and } \\
\text { Addeo }\end{array}$ & 2007 & $\begin{array}{l}\text { Three gratifications: relationships, integrated use, info- } \\
\text { entertainment }\end{array}$ \\
\hline Hoştut & 2010 & $\begin{array}{l}\text { Four gratifications: relaxation, sociability and reassurance, } \\
\text { status and fashion, and innovation }\end{array}$ \\
\hline $\begin{array}{l}\text { Al-Barashdi, Bouazza, } \\
\text { Jabur, and Zubaidi }\end{array}$ & 2015 & $\begin{array}{l}\text { Six gratifications: social interaction, information sharing } \\
\text { and entertainment, self-identity and conforming, self- } \\
\text { development and safety, freedom and privacy, self- } \\
\text { expression and gossip }\end{array}$ \\
\hline
\end{tabular}

Recently, mobile uses and gratifications research has also identified social gratification as a usage factor that motivates mobile use (Stafford \& Gillenson, 2004). Social gratification arises due to the mobility, Internet, and social function provided by the mobile phone. With the mobile phone acting as a social media most of the time, social interaction with family members, friends, colleagues, and acquaintances becomes an important motivation for people to use it.

Therefore, using U\&G as a premise, we postulate that the flood victims actively used the mobile phone to satisfy their needs in getting the latest and most updated information about the flood incident, to socialise with family and friends, and to entertain themselves during the disaster as not much could be done during the incidence.

Therefore, based on previous literature, the theoretical framework, and the discussion above, the following hypotheses are proposed:

- H1: Age is negatively related to the usage of mobile phones.

- H2: Perceived importance of using mobile phones is positively related to the usage of mobile phones.

- H3 (a): Entertainment gratification is positively related to the usage of mobile phones.

- H3 (b): Social gratification is positively related to the usage of mobile phones.

- H3 (c): Mobile and convenience gratification are positively related to the usage of mobile phones. 


\section{METHODOLOGY}

This study employs the quantitative approach with a cross-sectional survey as the research method in exploring the use of mobile phones during the 2014 flood in Malaysia. A survey questionnaire is disseminated among 507 flood victims from three different states in the East Coast of Malaysia (Pahang, Terengganu, and Kelantan).

Two different measures are used to capture the pattern of mobile phone usage during the 2014 flood in Malaysia. First, the respondents are asked to rate their frequency of making and receiving phone calls per day. They are also requested to rate the extent of their mobile phone usage, i.e., using the various features available on the mobile phone, such as text messages, blue tooth, voice mail messages, and multimedia messages, and this variable is measured using a 5-point Likert scale with response items ranging from 1 (Never) to 5 (Always). Eleven items are included in this measure, and a composite score of mobile phone usage is obtained by averaging the scores from these items. The higher the score, the more extensive their use of the mobile phone would be.

Next, other aspects related to mobile phone usage are also measured, i.e., reasons for using the mobile phone during the flood and perceived importance of using the mobile phone during the flood. First, respondents are asked to rate their reasons for using the mobile phone using a 5-point Likert scale, and 13 items are included in this measure with response items ranging from 1 (Never) to 5 (Always). An example of an item in this measure is: "I use the mobile phone to stay in contact with my friends". Next, respondents are also asked to rate the level of importance in using the mobile phone using a 5-point Likert scale with the response items ranging from 1 (Not Important) to 5 (). Finally, respondents are also asked to provide the level of satisfaction or gratification that they sought from using the mobile phone with a 5-point Likert scale. Three different gratifications are included in this measure: using the mobile phone to satisfy entertainment needs ( 5 items), using the mobile phone to satisfy social needs (5 items), and using the mobile phone during the flood due to its mobility and convenience ( 9 items). The response items for this scale ranged from 1 (Strongly Agree) to 5 (Strongly Disagree). Examples of items used for this measure are "Using the mobile phone is interesting" (entertainment), "I use the mobile phone to feel closer to family members in times of need" (social), and "I use the mobile phone because it provides immediate access to facilitate sharing of sorrow after the flood" (mobility and convenience). All variables used in this study are also subjected to reliability testing, and based on that analysis, the Cronbach's alpha values indicate that all measures used in this study are highly reliable with scores ranging from .81 to .92 .

\section{RESULTS AND DISCUSSION}

Based on the 507 flood victims from three different states (Pahang, Terengganu, and Kelantan) who participated in the study, $63 \%$ of the respondents in the study are females while the rest $(37 \%)$ are males. These flood victims are relatively young $(M=35.90, S D=14.39)$, with age that ranges from 14 to 76 . More than half of them are married (55\%), while others are single $(39 \%)$, and a minority are either divorced $(1 \%)$ or widowed $(3 \%)$. One-third of the respondents are well educated with at least a bachelor's degree (31\%), $24 \%$ are diploma holders, and more than one-third completed at least a secondary school education (35\%). However, only $2 \%$ have a post-graduate education, while another $2 \%$ do not possess any formal education. They are also required to report their employment status; most are gainfully employed 
and working full-time (60\%). Some have professional positions $(24 \%)$, while others work in sales and services $(26 \%)$ or administration and management $(20 \%)$. Also, almost half of the respondents (47\%) are from households with relatively low income, earning RM200 or less per month. Finally, a majority of the flood victims stay in villages (42\%) or terrace houses $(30 \%)$ and consist of nuclear families with parents and children $(78 \%)$, with an average of six family members staying in one household.

\section{The pattern of mobile phone usage}

Two variables are used to measure the pattern of mobile phone usage during the flood period. First, respondents provide their different usage of mobile phones during the 2014 flood. From the data provided (Table 2), the mobile phone is mostly used to make and receive calls; almost half of the respondents use the mobile phone all the time to make calls $(48 \%)$ and receive calls (45\%). Other popular usage of the mobile phone during the flood are to send and receive text messages and to take photos.

\section{Table 2: Extent of Using Various Features/Facilities Provided by Mobile Phones}

\begin{tabular}{lccccc}
\multicolumn{1}{c}{ Items } & 1 & 2 & 3 & 4 & 5 \\
For making calls & 17 & 39 & 71 & 135 & 245 \\
& $(3.45 \%)$ & $(7.7 \%)$ & $(14 \%)$ & $(26.6 \%)$ & $(48.3 \%)$ \\
For receiving calls & 13 & 33 & 74 & 155 & 232 \\
For sending text messages & $(2.6 \%)$ & $(6.5 \%)$ & $(14.6 \%)$ & $(30.6 \%)$ & $(45.8 \%)$ \\
& 32 & 46 & 94 & 148 & 187 \\
For receiving text messages & $(6.3 \%)$ & $(9.1 \%)$ & $(18.5 \%)$ & $(29.2 \%)$ & $(36.9 \%)$ \\
& 34 & 43 & 94 & 145 & 190 \\
For taking pictures/photos & $(6.7 \%)$ & $(8.5 \%)$ & $(18.5)$ & $(28.6 \%)$ & $(37.5 \%)$ \\
For receiving multimedia & 73 & 37 & 91 & 125 & 181 \\
messages & $(14.4 \%)$ & $(7.3 \%)$ & $(17.9 \%)$ & $(24.7 \%)$ & $(35.7 \%)$ \\
For sending multimedia & 188 & 69 & 99 & 69 & 82 \\
messages & $(37.1 \%)$ & $(13.6 \%)$ & $(19.5 \%)$ & $(13.6)$ & $(16.2 \%)$ \\
For voice mails messages & 185 & 80 & 103 & 60 & 79 \\
For exchanging things via & $(36.5 \%)$ & $(15.8 \%)$ & $(20.3 \%)$ & $(11.8 \%)$ & $(15.6 \%)$ \\
bluetooth & 249 & 79 & 87 & 47 & 45 \\
\hline
\end{tabular}

Note: The scores are 1 (Never), 2 (Rarely), 3 (Sometimes), 4 (Often), and 5 (Always)

\section{Reasons for using the mobile phone}

Based on Table 3, the most popular reason for always using the mobile phone during the flood period is to stay in contact with immediate family members (66\%). Also, other top reasons for always using the mobile phone during the flood period include staying in contact with other relatives $(48 \%)$ and getting informed of the flood status around their own housing 
area $(47 \%)$. It appears that concerns for immediate family members and relatives and their residential area influence the frequency of using the mobile phone during the flood period. Communication with relevant authorities appears to be done only periodically, with less than $20 \%$ of the respondents reporting to use the mobile phone all the time to keep in touch with the relevant authorities or to reduce their uncertainty about what to do next by contacting the relevant authorities.

Table 3: Reasons for using the mobile phone during the flood

\begin{tabular}{|c|c|c|c|c|c|}
\hline Items & 1 & 2 & 3 & 4 & 5 \\
\hline $\begin{array}{l}\text { To stay in contact with my } \\
\text { immediate family }\end{array}$ & $\begin{array}{c}5 \\
(1.0 \%)\end{array}$ & $\begin{array}{c}12 \\
(2.4 \%)\end{array}$ & $\begin{array}{c}39 \\
(7.7 \%)\end{array}$ & $\begin{array}{c}119 \\
(23.5 \%)\end{array}$ & $\begin{array}{c}332 \\
(65.5 \%)\end{array}$ \\
\hline To stay in contact with relatives & $\begin{array}{c}9 \\
(1.8 \%)\end{array}$ & $\begin{array}{c}25 \\
(4.9 \%)\end{array}$ & $\begin{array}{c}74 \\
(14.6 \%)\end{array}$ & $\begin{array}{c}158 \\
(31.2 \%)\end{array}$ & $\begin{array}{c}241 \\
(47.5 \%)\end{array}$ \\
\hline $\begin{array}{l}\text { To get informed of the status of } \\
\text { the flood around my house }\end{array}$ & $\begin{array}{c}29 \\
(5.7 \%)\end{array}$ & $\begin{array}{c}27 \\
(5.3 \%)\end{array}$ & $\begin{array}{c}61 \\
(12 \%)\end{array}$ & $\begin{array}{c}151 \\
(29.8 \%)\end{array}$ & $\begin{array}{c}239 \\
(47.1 \%)\end{array}$ \\
\hline $\begin{array}{l}\text { To stay in contact with my } \\
\text { friends }\end{array}$ & $\begin{array}{c}12 \\
(2.4 \%)\end{array}$ & $\begin{array}{c}36 \\
(7.1 \%)\end{array}$ & $\begin{array}{c}108 \\
(21.3 \%)\end{array}$ & $\begin{array}{c}126 \\
(24.9 \%)\end{array}$ & $\begin{array}{c}225 \\
(44.4 \%)\end{array}$ \\
\hline $\begin{array}{l}\text { To know what goes on } \\
\text { around me (neighbourhood/ } \\
\text { community) }\end{array}$ & $\begin{array}{c}27 \\
(5.3 \%)\end{array}$ & $\begin{array}{c}33 \\
(6.5 \%)\end{array}$ & $\begin{array}{c}71 \\
(14.0 \%)\end{array}$ & $\begin{array}{c}173 \\
(34.1 \%)\end{array}$ & $\begin{array}{c}203 \\
(40 \%)\end{array}$ \\
\hline To call for help in time of need & $\begin{array}{c}72 \\
(14.2 \%)\end{array}$ & $\begin{array}{c}37 \\
(7.3 \%)\end{array}$ & $\begin{array}{c}83 \\
(16.4 \%)\end{array}$ & $\begin{array}{c}117 \\
(23.1 \%)\end{array}$ & $\begin{array}{c}198 \\
(39.1 \%)\end{array}$ \\
\hline $\begin{array}{l}\text { To keep informed about what } \\
\text { is happening around the flood } \\
\text { area }\end{array}$ & $\begin{array}{c}41 \\
(8.1 \%)\end{array}$ & $\begin{array}{c}49 \\
(9.7 \%)\end{array}$ & $\begin{array}{c}103 \\
(20.3 \%)\end{array}$ & $\begin{array}{c}150 \\
(29.6 \%)\end{array}$ & $\begin{array}{c}164 \\
(32.3 \%)\end{array}$ \\
\hline $\begin{array}{l}\text { To stay in contact with } \\
\text { neighbours }\end{array}$ & $\begin{array}{c}30 \\
(5.9 \%)\end{array}$ & $\begin{array}{c}52 \\
(10.3 \%)\end{array}$ & $\begin{array}{c}127 \\
(25 \%)\end{array}$ & $\begin{array}{c}141 \\
(27.8 \%)\end{array}$ & $\begin{array}{c}157 \\
(31 \%)\end{array}$ \\
\hline $\begin{array}{l}\text { To keep up with news } \\
\text { happenings in the state }\end{array}$ & $\begin{array}{c}1 \\
(0.2 \%)\end{array}$ & $\begin{array}{c}27 \\
(5.3 \%)\end{array}$ & $\begin{array}{c}22 \\
(4.3 \%)\end{array}$ & $\begin{array}{c}74 \\
(14.6 \%)\end{array}$ & $\begin{array}{c}152 \\
(30 \%)\end{array}$ \\
\hline $\begin{array}{l}\text { To seek information on how to } \\
\text { get help }\end{array}$ & $\begin{array}{c}80 \\
(15.8 \%)\end{array}$ & $\begin{array}{c}59 \\
(11.6 \%)\end{array}$ & $\begin{array}{c}98 \\
(19.3 \%)\end{array}$ & $\begin{array}{c}131 \\
(25.8 \%)\end{array}$ & $\begin{array}{c}139 \\
(27.4 \%)\end{array}$ \\
\hline $\begin{array}{l}\text { To stay in contact with } \\
\text { colleagues/business partners } \\
\text { for work-related issues }\end{array}$ & $\begin{array}{c}114 \\
(22.5 \%)\end{array}$ & $\begin{array}{c}72 \\
(14.2 \%)\end{array}$ & $\begin{array}{c}138 \\
(27.2 \%)\end{array}$ & $\begin{array}{c}83 \\
(16.4 \%)\end{array}$ & $\begin{array}{c}100 \\
(19.7 \%)\end{array}$ \\
\hline $\begin{array}{l}\text { To stay in contact with the } \\
\text { relevant authority }\end{array}$ & $\begin{array}{c}133 \\
(26.2 \%)\end{array}$ & $\begin{array}{c}96 \\
(18.9 \%)\end{array}$ & $\begin{array}{c}106 \\
(20.9 \%)\end{array}$ & $\begin{array}{c}77 \\
(15.2 \%)\end{array}$ & $\begin{array}{c}95 \\
(18.7 \%)\end{array}$ \\
\hline $\begin{array}{l}\text { To ask the relevant authority } \\
\text { on what should be done next }\end{array}$ & $\begin{array}{c}157 \\
(31 \%)\end{array}$ & $\begin{array}{c}80 \\
(15.8 \%)\end{array}$ & $\begin{array}{c}110 \\
(21.7 \%)\end{array}$ & $\begin{array}{c}77 \\
(15.2 \%)\end{array}$ & $\begin{array}{c}83 \\
(16.4 \%)\end{array}$ \\
\hline
\end{tabular}

Note: The scores are 1 (Never), 2 (Rarely), 3 (Sometimes), 4 (Often), and 5 (Always)

\section{Gratification and satisfaction obtained from using the mobile phone during the 2014 flood}

The respondents are also asked about the gratification and satisfaction obtained from mobile phone use (Table 4). Based on the results, flood victims use the mobile phone to satisfy their social needs to communicate with others during the flood $(M=4.46, S D=.67)$ rather than 
to satisfy entertainment needs $(M=4.27, S D=.73)$ or due to the mobility needs $(M=4.13$, $S D=.80)$.

Table 4: Gratification and satisfaction obtained from mobile phone use

\begin{tabular}{|c|c|c|}
\hline Items & Mean & SD \\
\hline Entertainment Gratification & 4.27 & .73 \\
\hline Social Gratification & 4.46 & .67 \\
\hline Mobility and Convenience Gratification & 4.13 & .80 \\
\hline
\end{tabular}

\section{The relationships among age, perceived importance of using the mobile phone, gratifications from using the mobile phone, and mobile phone usage during the 2014 flood in Malaysia}

This study also examines the variables that would predict extensive mobile phone use during the flood period by using the hierarchical regression analysis (Table 5). In Step 1, age is entered into the equation. In Step 2, perceived importance of using the mobile phone when making and receiving calls is entered into the equation. Finally, the three gratifications simultaneously obtained from using the mobile phone (i.e., entertainment, social, and mobility gratification) are entered in Step 3. Extensive use of the mobile phone serves as the dependent variable in this analysis.

\section{Table 5: Summary of Regression Analysis for Predicting Mobile Phone Usage During the 2014 Flood in Malaysia}

\section{Variable}

Step 1

Age

Step 2

Age

Perceived Importance of Mobile Phone Use

Step 3

Age

Perceived Importance of Mobile Phone Use

Entertainment Gratification

Social Gratification

Mobility \& Convenience Gratification

\section{B}

$-.01$

.00

$-2.27^{* *}$

$\beta$

$\begin{array}{ccc}-.13 & .00 & -2.08^{* *} \\ .17 & .04 & .17^{* *}\end{array}$

Note. Step 1: $R=.23, R^{2}=.05, p<.001$, Step 2: $R=.29, R^{2}=.08, \Delta R^{2}=.03, p<.01$, Step 3: $\Delta R^{2}$ $=.16$. Total $R^{2}=.24, p<.001$, Total Adj. $R^{2}=.23$. ${ }^{*} p<.05,{ }^{* *} p<.001$.

In Step 1, age emerges as a significant predictor of extensive mobile phone use $(\beta=-.23, p<$ $.01)$, where as predicted, younger mobile phone users are more likely to use the mobile phone 
extensively during the flood period. Therefore, H1 is supported. In Step 2, the perceived importance of using the mobile phone also emerges as a significant positive predictor of mobile phone usage $(\beta=.17, p<.01)$. Therefore, $\mathrm{H} 2$ is supported. Also, age remains a significant predictor at this step $(\beta=-.21, p<.01)$. Together, they account for an additional $2.9 \%$ of the variance, and the $F$ change is significant $(p<.01)$. In Step 3 , when the three gratifications of using mobile phones are entered into the equation, they account for an additional $15.5 \%$ of the variance explained, and the $F$ change is also significant $(p<.01)$. Age $(\beta=-.18, p<.01)$ and the perceived importance of using the mobile phone $(\beta=.09, p<.05)$ remain as significant predictors at this step, while mobility $(\beta=.23, p<.01)$ and entertainment gratifications $(\beta=$ $.23, p<.01)$ emerge as significant, positive predictors of mobile phone usage. However, social gratification does not significantly predict extensive mobile phone usage. Therefore, both $\mathrm{H} 3$ (a) and H3 (c) are supported, while H3b is not supported. The final equation accounts for $23 \%$ of the variance explained in mobile phone usage among flood victims during the 2014 flood period in Malaysia.

\section{DISCUSSION}

Based on the overall findings, the data underscore the importance of the mobile phone as a ubiquitous and convenient communication tool, especially during disaster periods such as floods. The flood victims reported frequent communication with others during the flood period, especially through making and receiving calls and using text messages. The mobile phone also appears to be very important in staying in contact with loved ones such as family members and relatives and finding updated information about the flood, particularly in their housing area affected by the flood.

Based on the regression analysis, it is also apparent that younger mobile phone users are more motivated to use mobile phones extensively during the flood period, and satisfaction obtained from entertainment and mobility needs tend to predict increased frequency in using the mobile phone as a communication tool during the flood period. These findings support previous studies on mobile phone uses and gratifications (Al-Barashdi, Bouazza, Jabur, \& Zubaidi, 2015; Leung \& Wei, 2000; Mazzoni, Castaldi, \& Addeo, 2007). It is possible that the stressful environment surrounding the flood period necessitates frequent and varied use of the mobile phone, as using the mobile phone helps to keep flood victims calm and entertained and reduce the stress level associated with dealing with and managing the ongoing flood (Ho \& Syu, 2010). Also, as a flexible and convenient communication tool, even when confined to their homes with reduced mobility, continued use of the mobile phone throughout the flood period is possible. Thus, by satisfying mobility and entertainment needs, mobile phone users are more motivated to use the mobile phone extensively throughout the flood period.

As digital natives, younger mobile phone users are also more likely to feel comfortable using the mobile phone to gratify their many different needs, as mediated communication is part and parcel of their everyday life. Also, as they are more technologically savvy than the middle-aged or older adults, they can fully maximise and utilise the many different apps available in their mobile phones to gratify a wide range of needs (i.e., playing mobile games to reduce boredom and using Facebook app to obtain information). Finally, although the mobile phone can provide updated and timely information about the flood, compared to younger users, older adults may be more reticent to use it as a primary source of information due to perceived low credibility and trust issues. Instead, they may have a stronger preference to 
utilise more traditional media (such as television and radio) to gratify their informational needs.

Further, findings also indicate that gratification obtained from satisfying social needs does not appear to predict extensive mobile phone use, and this is rather puzzling. However, since flood victims may already be continuously communicating with close family members and friends extensively throughout the flood period through face-to-face communication, perhaps this explains why satisfaction obtained from social needs through mobile phone use does not predict further mobile phone use. Also, social needs can be satisfied through other means besides face-to-face communication and mobile phones, such as using social media (i.e., Facebook, Twitter, Instagram) through other mobile devices, such as tablets and computers (Bunce et al., 2012; Tengku Siti Aisha et al., 2015). Nevertheless, findings in this study on gratification satisfied through the mobile phone, as well as mobile phone use appear to lend partial support to the assumptions of uses and gratifications, where gratification obtained when using certain media can predict further use of that media. Thus, specifically, when mobile phone users believe that the mobile phone is likely to satisfy their entertainment needs and that it is convenient, they are more likely to use it extensively.

\section{LIMITATIONS OF THE STUDY}

This study has its limitations. The major limitation of this study is that the relatively small sample was restricted to flood victims living in the East Coast of Malaysia. The results, therefore, cannot be generalised to all victims involved in a natural disaster other than floods or to flood victims in other states in Malaysia. Also, these findings are based on the quantitative approach of the experience of flood victims; future studies could utilise the qualitative approach to further explore the uses and gratifications of mobile phones during disaster periods. Also, this study focuses on only three types of gratification sought when using the mobile phone. Future studies could concentrate on other gratifications provided by mobile phone usage such as self-development and safety (Al-Barashdi, Bouazza, Jabur, \& Zubaidi, 2015) or instrumentality and reassurance (Dimmick, Sikand, \& Patterson, 1994) that may affect the uses and gratifications of mobile phones during flood periods.

\section{CONCLUSION}

This paper highlights mobile phone usage among flood victims in the East Coast of Malaysia. Undeniably, the mobile phone is a valuable communication tool in managing communication with relatives and close friends during the flood period. Reduced mobility, portability of mobile phones as a communication tool, and interrupted or inconsistent electricity service all contribute to high usage of mobile phones during the flood period. It is recommended that government agencies and other organisations fully utilise mobile phones as a telecommunication device to relay updated information (e.g., flood status) or to mobilise help to aid flood victims through either SMS services or calls. This will ensure a more efficient flood management and aid recovery process for flood victims. It may even help save lives and reduce physical and emotional damage caused by the flood. 


\section{REFERENCES}

Al-Barashdi. (2015). Smartphone gratifications among Sultan Qaboos University undergraduates: A mixed-approach investigation. British Journal of Education, Society $\mathcal{E}$ Behavioural Science, 10(1), 1-17.

Anthony, K. E. \& Sellnow, T. L. (2011). Information acquisition, perception, preference, and convergence by gulf coast residents in the aftermath of the hurricane Katrina crisis. Argumentation and Advocacy, 48, 81-96.

Blumler, J. G. \& Katz, E. (1974). The uses of mass communications: Current perspectives on gratifications research. SAGE Annual Reviews of Communication Research, volume III. CA: Sage Publications.

Bunce, S., Partridge, H., \& Davis, K. (Feb 2012). Exploring information experience using social media during the 2011 Queensland Floods: A pilot study. Australian Library Journal; 61(1); ProQuest Education Journals, 34-45.

Chen, Y., Chen, V., Lo, R., Xiaoge, X., \& Guoliang, Z. (2014). A comparative study of the relationship between mobile phone use and social capital among college students in Shanghai and Taipei. International Journal of Journalism \& Mass Communication, 1(105), 1-9.

Cho, S. E. \& Park, H. W. (Nov 2011). Social media use during Japan's 2011 earthquake: How Twitter transforms the locus of crisis communication. Media International Australia, 149, $28-40$.

Dimmick J. W., Sikand, J., \& Patterson, S. J. (1994). The gratification of the household telephone. Communication Research, 21(5), 643-664.

Ho, H. \& Syu, L. (2010). Uses and gratifications of mobile application users. International Conference on Electronics and Information Engineering (ICEIE 2010), 1, 315-319.

Hoppszallern, S. (2014, March). Tweeting and texting during disasters. Hospitals \& Health Networks, 88/3(20), 1068-8838.

Hoştut, S. (2010). Uses and gratifications of mobile phone use among students in Turkey. Retrieved from $h$ ttps://www. researchgate.net/publication/265466140 on 17/05/2016

J-F., Pullen, D., \& Swabey, K. (2014). Adolescent use of mobile phones: A social context. Australian Educational Computing, 29(1), 1-10.

Katz, E., Blumler, J. G., \& Gurevitch, M. (1973).The uses and gratification research. The Public Opinion Quarterly, 37(4), 509-523.

Kavanaugh, A., Sheetz, S. D., Quek, F., \& Kim, B. J. (2010). Cell phone use with social ties during crises: The case of the Virginia Tech Tragedy. Paper presented at $7^{\text {th }}$ International Conference on Information Systems for Crisis Response and Management (ISCRAM). Seattle, WA. Retrieved from http://opus.ipfw.edu/dpea_facpres/53 on 19/04/2016

Kryvasheyeu Y., Chen, H., Moro, E., Hentenryck, P., \& Cebrian, M. (2015). Performance of social network sensors during hurricane Sandy. PLoS ONE. 10(2).

Leung, L. \& Wei, R. (2000). More than just talk on the move: Uses and gratifications of the cellular phone. Journalism and Mass Communication Quarterly, 77(2), 308-320.

Liu, B. F., Fraustino, J. D., \& Jin, Y. (2015). Social media use during disasters: How information form and source influence intended behavioral responses. Communication Research, 38(1), 189-213. Retrieved from www.crx.sagepub.com on 29/11/2015 
Malaysian Communications and Multimedia Commission (MCMC) (2014). Handphone users survey 2014. Retrieved from http://www.skmm.gov.my/Resources/Statistics/Handphone-Surveys.aspx on 12/07/2016

Mazzoni, C., Castaldi, L., \& Addeo, F. (2007). Consumer behavior in the Italian mobile telecommunication market. Telecommunications Policy, 31, 632-647.

Özcan, Y. Z. \& Koçak, A. (2003). A need or a status symbol? Use of cellular telephones in Turkey. European Journal of Communication, 18(2), 241-254.

Perry, S. D. (November 2007). Tsunami Warning Dissemination in Mauritius. Journal of Applied Communication Research, 35(4), 399-417.

Reuters (2014, December 26). Record numbers evacuated in Malaysia's worst flood in decades. Retrieved from http://www.investing.com/news/world-news/record-numbersevacuated-in-malaysia 's-worst-floods-in-decades-321473 on 20/04/2016

Robin L. N., Carmen R. S., Jeff, H., \& Keli, L. (2006): Emotional and cognitive predictors of the enjoyment of reality-based and fictional television programming: An elaboration of the uses and gratifications perspective, Media Psychology, 8(4), 421-447.

Ruggiero, T. (2000). Uses and gratifications theory in the 21st century. Mass Communication E Society, 3(1), 3-37.

Simon, T., Goldberg, A., Aharonson-Daniel, L., Leykin, D., \& Adini, B. (2014, August). Twitter in the cross fire - The use of social media in the Westgate Mall terror attack in Kenya. PLOS One (free open access journal) 9(8), 1-11.

Sutton, J., Palen, L., \& Shklovski, I. (2008, May). Backchannels on the front lines: Emergent uses of social media in the 2007 Southern California wildfires. Proceedings of the 5th International ISCRAM Conference, Washington: USA, May 2008.

Tanner, A., Friedman, D. B., Koskan, A., \& Barr, D. (2009). Disaster communication on the Internet: A focus on mobilizing information. Journal of Health Communication, 14, 741-755.

Tanta, I., Mihovilović, M., \& Sablić, Z. (2014). Uses and Gratification Theory - Why adolescents use Facebook? Medij. istraž. 20(2), 85-110. Retrieved from http://hrcak.srce.hr/133809 on 13/03/2016

Tengku Siti Aisha, Saodah Wok, Aini Maznina A Manaf \& Rizalawati Ismail (2015). Exploring the use of social media during the 2014 flood in Malaysia. Procedia - Social and Behavioral Sciences, retrieved from www.sciencedirect.com on 23/02/1016

Umihara, J. \& Nishikitani, M. (2013, July). Emergent use of Twitter in the 2011 Tohoku earthquake. Prehospital and Disaster Medicine, 28(5), 434-440.

Wei, R. (2006). Motivations for using the mobile phone form mass communication and entertainment. Telematics and Informatics, 25(1), 36-46. 